\title{
No More Scandals: A Simple Model For Valuing Employee Stock Options
}

\author{
J. Howard Finch, (E-mail: jhfinch@fgcu.edu), Florida Gulf Coast University \\ Joseph C. Rue, (E-mail: jrue@fgcu.edu), Florida Gulf Coast University \\ Ara G. Volkan, (E-mail: avolkan@fgcu.edu), Florida Gulf Coast University
}

\begin{abstract}
The escalating size of compensation packages to senior managers and investor disillusionment have resulted in growing calls for the expensing of employee stock options (ESO). While initially slow to respond, the FASB has now mandated the expensing of ESO. The two primary methods used to value ESO, the Black-Scholes closed form equation and the lattice model, suffer from several deficiencies. A Simple model for valuing ESO that marks the option expense to market in succeeding financial statement dates and allows for the staggered exercise dates of option holders is available. The model is easy to understand, would have a low cost of implementation, and offers a superior estimate of the true cash flow effects associated with the opportunity cost to shareholders of ESO exercise.
\end{abstract}

\section{INTRODUCTION}

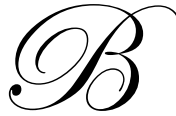

ackdating the grant date is the latest scandal involving employee stock options (ESO). Given that the strike price of ESO is usually set to equal the market price of the stock at the grant date and assuming rising stock prices, backdating occurs when the original grant date is moved back to allow the grantee to immediately have a favorable spread between the backdated, lower strike price of the option and the current, higher stock price. Option accounting rules require that an expense be recognized immediately for such transactions for the difference between the lower, backdated price and the higher, current price. In several cases backdating was done without the approval of the board of directors. In addition, neither the appropriate expense was recognized nor did the financial statements contain the required disclosures. As a result, the Securities and Exchange Commission (SEC) is forcing many companies to restate their prior earnings. Finally, the Department of Justice is bringing criminal and civil charges against executives involved in these schemes, claiming that the defendants have effectively given themselves an opportunity to place bets in the middle of a race and avoided paying tax on their winnings.

Firms that use ESO as a method of compensation have wrestled with the issue of timing and measurement of expense recognition for years. Recent accounting standards call for the immediate recognition of compensation costs related to share-based employee awards in firms' financial statements. However, the method of valuing such options has not been specified, leaving financial managers and investors with difficult decisions regarding the choice of valuation model and the resulting impact on financial performance. In addition, the current standards call for expense recognition only during the vesting (mandatory employment) period, disregarding the impact of options on financial position after vesting but before exercise.

\section{PURPOSE}

The purpose of this paper is to compare and contrast the existing models for ESO valuation, and to offer a different model which more readily captures the wealth effects on shareholder value. Since valuing and expensing options have been accepted by stakeholders, it is time to take the final step of starting to mark options to market until they are exercised and capture the true cost of these transactions in company financial statements. 


\section{BACKGROUND}

The history of whether or not firms should recognize the expense associated with issuing ESO, and the valuation method used to determine the expense, is extensive. In 1972, the Accounting Principles Board issued Opinion No. 25, which tied the valuation of the ESO to its intrinsic value. If, on the initial grant date, the exercise price of the option was greater than or equal to the current market price of the firm's stock (at or out of the money), the firm was not required to recognize any expense (APB, 1972). The only instance where initial expense recognition was required was if the option was in the money at the grant date. The value of the option was recognized as its intrinsic value, the positive difference between the stock price and the option exercise price, and this valuation method was known as the intrinsic value method.

Financial managers know that the value, or price, of an option is comprised of two components, the intrinsic value and the time value. Between 1978 and 1993, the Financial Accounting Standards Board (FASB) acknowledged this by issuing several documents arguing for a change in emphasis in the valuation of ESO from intrinsic value to fair value (FASB, 1978, 1985, 1986, and 1993; FASC-AAA, 1994). The discussion in these documents did not specify the valuation model to be used. In 1995, the FASB issued Standard no. 123 which encouraged, but did not mandate, that firms recognize the expense associated with the issuance of ESO using a fair valuation method. A firm choosing not to expense was required to disclose the effect of ESO on financial statements in a footnote (FASB, 1995). Again, the method of valuation was left to up to financial management.

Rising levels of CEO compensation and investor unrest led to increasing calls for the immediate expense recognition for ESO in corporate financial statements (Apostolou and Crumbley, 2001 and 2005; Bartow and Mohanram, 2004; Botosan and Plumlee, 2001; Delves, 2002; Doyle, 1997; Mellman and Lillien, 1996; Moyer and Weihrich, 2000). While the FASB continued to issue documents concerning ESO (FASB, 2002a and 2002b), strong opposition from firms fearful of negative impacts on their financial position resulted in a stand-off over the ensuing decade. Finally, in December 2004 the FASB issued Standard No. 123 (R) that requires firms to recognize compensation costs related to share-based transactions in their financial statements and brings global harmony to accounting for ESO (IASB, 2002 and 2004). All firms were required to be in compliance with this directive by the end of 2005. Originally, FASB favored the use of a lattice model for option valuation, but backed off due to significant opposition from various stakeholders (FASB, 2004). While still not specifying a specific option valuation model to be used, the directive does indicate a closed form equation model or a lattice model approach as appropriate for valuing ESO.

\section{ALTERNATIVE OPTION VALUATION MODELS}

From a financial investment perspective, the true economic cost to a firm of utilizing ESO as a method of compensation is the opportunity cost associated with the difference between the exercise price of the option and the market price of the stock upon exercise. This intrinsic value represents foregone capital that could have been raised by the firm if the stock had been issued directly at current market prices. Therefore, the choice of which option valuation model should be used to recognize the ESO expense should be driven by the determination of which model most accurately reflects this loss of shareholder wealth (Aboody, Barth, and Kasznik, April 2004; Balsam, 1994; Baviera and Walther, 2004; Best, Rue, and Volkan, 2002; Briloff, 2003; Dechow and Sloan, 1996; Deshmukh, Howe, and Luft, 2004; Dyson, 2004; Hill and Stevens, 1997; Hull and White, 2004; Lobo and Rue, 2000; Pacter, 2004; Perspectives, 1994; Rue, Volkan, Best, and Lobo, 2003; Siegel, 2006; Tucker and Shimko, 1995; Wallace, 1984).

Since 1995, many firms have voluntarily acknowledged the effects of ESO on financial results through footnote disclosures, using the Black-Scholes (BS) or Black-Scholes-Merton (BSM, for stocks that pay dividends) model for option valuation (Aboody, Barth, and Kasznik, May, 2004; Beams, Amoruso, and Richardson, 2005; Robinson and Burton, 2004). The BS model is a closed form equation that, when supplied with several estimated variables, computes a fair option value that includes both intrinsic and time value (Black and Scholes, 1973). Eaton and Prucyk (2005) provide an illustration of the BSM option valuation method using Excel spreadsheet software. 
However, a number of issues make the BS model a poor choice for option valuation to reflect the ESO expense recognition (FASC-AAA, 2004 and 2005; Hemmer, Matsunaga, and Shevlin, 1994; Kirschenheiter, Mathur, and Thomas, 2004; Moehrle and Reynolds-Moehrle, 2004). First, the model was originally developed to value exchange-traded options that have limited lives. The typical ESO has a longer life (five to ten years) that often begins when a required vesting period ends. Exchange traded options also have a liquid secondary market that facilitates low cost transactions, resulting in regular price discovery. In contrast, the ESO are not transferable. In addition, BS was developed to value a European option that cannot be exercised until maturity. Once the vesting period is complete, the ESO can be exercised at the discretion of the employee, in effect an American option. Finally, a key input in the BS model is volatility. Most volatility estimates are derived from historical returns, leaving no opportunity for the incorporation of changing market conditions and the resulting effects on shareholder wealth.

A lattice model based on a series of discrete future price paths is an alternative option valuation method. The simplest lattice is a binomial model that assumes the current stock price can diverge one of two possible paths in the coming period. There is some sentiment that a lattice valuation model is superior to the BS model for the ESO expense recognition. Barenbaum, Schubert, and O'Rourke (2004) highlight two advantages of a lattice model, including an ability to incorporate varying exercise patterns on the part of option holders and the flexibility to capture changes in the volatility of the underlying stock's rate of return. The authors note that the possibility of early exercise reduces the total option value at the grant date (reducing the time value of the option price), and thus the overall impact on reported earnings is less when the ESO are valued using a lattice model. Baril, Betancourt, and Briggs (2005) provide an illustration of ESO valuation using a lattice model program in Excel spreadsheet software.

\section{PROBLEMS WITH EXISTING MODELS}

Consider the following example; a firm issues an at the money call option as part of an ESO plan. The current stock price and exercise price on the call are $\$ 100$, the risk free rate of interest is $7 \%$, and the firm wishes to value the option for expense recognition purposes. The options vest in three years. Assume no dividends are paid on this stock. Since, the BS model requires an estimate of return volatility, typically taken from historical data, assume the standard deviation of the returns is $25 \%$. Then,

$C=S_{0} N\left(d_{1}\right)-X e^{-r c t} N\left(d_{2}\right)$; where, $d_{1}=\left[\ln \left(S_{0} / X\right)+\left(r_{c}+\left(\sigma^{2} / 2\right)\right) T\right] / \sigma \sqrt{ }$ and $d_{2}=d_{1}-\sigma \sqrt{ } T$.

Converting $7 \%$ to a continuously compounded equivalent of $7.25 \%$, the results are $\mathrm{d}_{1}=.7189$, and $\mathrm{d}_{2}=$ .6103. This converts to a cumulative normal probabilities of $\mathrm{N}\left(\mathrm{d}_{1}\right)=.7611$ and $\mathrm{N}\left(\mathrm{d}_{2}\right)=.6103$. Solving for the call value,

$\mathrm{C}=100(.7611)-100 \mathrm{e}^{-.0725(3)}(.6103)=\$ 27.00$

The lattice, or binomial, model requires explicit assumptions regarding the discrete increase or decrease in the changes of the price of the stock at the end of each period of the option's life. Assuming that the stock price may either rise by $25 \%$ or fall by $20 \%$ each period, the probability of a rise is given by

$\mathrm{P}=1+\mathrm{r}-\mathrm{d} / \mathrm{u}-\mathrm{d}$

$\mathrm{P}=1.07-.80 / 1.25-.80$

$\mathrm{P}=.60$ and the probability of a fall, $(1-\mathrm{p})=.40$.

Then, a multi-period binomial valuation for a call option is given by

$$
\begin{aligned}
& \mathrm{C}=\sum \mathrm{j}=0 \text { to } n \quad\left(n ! / \mathrm{j} !(\mathrm{n}-\mathrm{j}) ! \mathrm{p}^{\mathrm{j}}(1-\mathrm{p})^{\mathrm{n}-\mathrm{j}} \operatorname{Max}\left[0, \mathrm{Su}^{\mathrm{j}} \mathrm{d}^{\mathrm{n}-\mathrm{j}}-\mathrm{X}\right]\right. \\
& (1+\mathrm{r})^{\mathrm{n}} \\
& \mathrm{C}=(0+0+10.80+20.59) /(1.07)^{3} \\
& \mathrm{C}=\$ 25.62
\end{aligned}
$$


Rue, Volkan, Best, and Lobo (2003) argue that these models do not capture the true cost to shareholders of issuing the ESO. First, current requirements call for option valuation at the grant date and expense recognition starting at the option grant date and over the vesting period. However, as the value of the firm's stock price changes, and the time until vesting changes, the value of the ESO changes as well. Thus, the ESO should be revalued at each reporting date, reflecting a dynamic expense rather than a one-time, static valuation. Also, valuation should not be truncated at the option vesting date. Because the timing of the exercise is dynamic, and lies with the option holder, a good valuation method should allow for extending the expense period from the vesting date to the actual exercise date. True expense recognition would require the option's value to be marked to market at regular financial reporting periods to reflect changing market conditions.

Interestingly, a precedent exists for this method of valuation. A stock appreciation right (SAR) represents a right to future cash flows associated with the difference between a base price and the actual market price at a future date. This difference is analogous to the intrinsic value of a call option. The valuation of the SAR in practice is dynamic, and is based on the current market price of the underlying shares.

\section{A SIMPLE ALTERNATIVE ESO VALUATION MODEL}

If the intent of the FASB is to force firms to disclose the true economic cost to shareholders of issuing the ESO, then a model is needed that will allow accounting for changing economic conditions and flexible timing of exercise by option holders. Rue, Volkan, Best, and Lobo (2003) propose a model that incorporates these considerations. The total ESO expense under the Simple model (S) is defined as follows:

$\mathrm{S}=($ period-end stock price - ESO exercise price $) \mathrm{x}$ the total ESO outstanding.

This calculation captures the intrinsic value of the total outstanding ESO obligation at the end of each financial reporting period. Financial statements would then record as expense (with a corresponding credit to paid-in capital from ESO):

Current ESO expense $=(\mathrm{S}-$ sum of previous expenses accrued $)$.

Thus, under the Simple method, the current calculated amount of the ESO expense represents the incremental, or marginal, increase in the opportunity cost the firm has incurred since the last reporting period. This is the true economic cost to the firm for the reporting period and represents a dynamic estimate of the cost to shareholders resulting from the negative opportunity cash flows associated with the ESO exercise.

\section{ADVANTAGES AND DISADVANTAGES}

While the expense computation under the Simple model is straightforward and dynamic, the expense computations under the BS and lattice models are static and are based on historical costs. Under both BS and lattice models, an initial option value is computed at the grant date. This value is amortized on a straight-line basis over the number of reporting periods between the grant date and the date options vest (i.e., when the mandatory employment period ends). For example, if the mandatory service period to qualify for options is three years, the amortization period is 12 quarters. Therefore, one-twelfth of the option value computed at the grant date is expensed during each quarter and until the options vest, with no adjustments made to the original amount (using the examples in the previous section - $\$ 27.00$ per option divided by twelve under the BS model versus $\$ 25.62$ per option divided by twelve under the lattice model). Thus, the current ESO accounting rules may result in situations where expenses are recognized for options that are no longer in the money.

In contrast, the option would have a value of zero under the Simple model at the grant date (typically, the strike price is set equal to the market price of the stock in question). At the end of each of the following quarters and until the employee exercises the option (at least equal to or longer than the 12 quarters used for the vesting period in the preceding example) the difference between the market price and the strike price at the end of each quarter represents the option expense, reduced by the sum of the expenses recognized in previous quarters. Thus, there would 
be no expense in a quarter when there is a decline in the market price of the stock from the previous quarter. Under such a scenario there would be a recovery of a portion of previously recognized expenses, an amount which is an accurate representation of the economic reality and the cash flow consequences of the ESO in that quarter.

Thus, the Simple model has several advantages over the BS and lattice models. First, it is easy to understand. Second, it does not require high implementation costs. Most importantly, it results in an expense amount that represents market conditions at the time when financial results are reported. Together with the fact that the Simple model reflects the cash flow effects on shareholder wealth associated with ESO, it should be an attractive alternative to current option valuation models.

\section{OBSTACLES TO ADOPTION}

By far the biggest obstacle against the adoption of any option valuation model is the resulting negative impact on reported earnings. Best, Rue, and Volkan (2002) observed the impact of different option expensing methods on the EPS of firms with similar quarterly outcomes, and found the dynamic approach to option expense measurement superior to the FASB 123 methods in reflecting cash flow consequences to the firm. However, if those consequences are higher costs associated with the ESO exercise, firms will resist implementing the method without regulatory mandate.

In addition, the FASB has indicated that any valuation method used must incorporate all six variables that influence an option's value, including the underlying share price, the exercise price, the time to maturity (or exercise), the volatility in the rate of return on the underlying shares, the risk-free rate (time value of money), and the dividend yield, if applicable. The Simple model explicitly incorporates the share price and exercise price. Volatility and time value are not an issue, since in effect at each reporting period the expense is marked to market to reflect current economic conditions. Likewise, the dividend yield is not relevant for the expense estimation, since the model is based on the cost associated with immediate exercise.

Another obstacle is the scope of the definitions of expenses and equities provided in the Statement of Financial Accounting Concepts No. 6 (SFAC 6). Under these definitions, promises to issue stock at less than market value may not result in expenses, even though such promises result in negative cash flow consequences for the firm since the stock could have been sold at a higher price. To its credit, the FASB has recognized that SFAC 6 should be revised by issuing a pair of October 27, 2000 exposure drafts (file reference numbers 213B and 213C) concerning accounting for financial instruments with characteristics of liabilities, equities, or both, where the FASB noted its intention to amend the definition of liabilities and expenses to include obligations that can or must be settled by issuing stock. In addition, the FASB issued standard no. 150 as the first phase of implementing its views concerning accounting for financial instruments that have both equity and liability characteristics (FASB, 2003). As the FASB continues to implement this project, the accounting method proposed in this article may be used to measure and report total cash flow impact of options on sponsoring firms.

\section{SUMMARY AND CONCLUSIONS}

Escalating compensation packages to senior managers and investor disillusionment have resulted in growing calls for the expensing of ESO. While slow to respond, the FASB mandated the expensing of the ESO. The two primary methods used to value the ESO, the Black-Scholes closed form equation and the lattice model, suffer from several deficiencies. These include different treatments of the possibility of early exercise, the need to derive volatility estimates that play a critical role in the valuation of the actual option amount, the lack of liquidity associated with secondary markets, and extended vesting periods.

A Simple model for valuing the ESO is available that is easy to understand, would have a low cost of implementation, and offers a superior estimate of the true cash flow effects associated with the opportunity cost to shareholders of the ESO exercise. By marking the option expense to market in succeeding financial statements, and allowing for the staggered exercise dates of option holders, the Simple model reflects the preference by investors to 
have the sponsoring firms disclose the shareholder wealth effect associated with the opportunity cost of the option exercise over time and up to the date of exercise.

In effect the Simple model represents a return to the original 1972 Opinion No. 25, which called for the recognition of the expense associated with the intrinsic value of an ESO. The Simple model is an improvement, however, in that the original opinion called for valuation on the option grant date. The fact that the Simple model reflects changing market conditions and incorporates staggered exercise (by utilizing the outstanding number of the ESO in the computation, rather than the original amount) makes it a superior method for acknowledging the true economic costs to shareholders of utilizing this method of employee compensation.

\section{RECOMMENDATIONS FOR FUTURE RESEARCH}

Future research may focus on the impact of expensing the ESO on stock values. A sample of S\&P 100 firms may be first compared to all large, diversified companies. Next, the same samples may be contrasted to a sample containing firms of all sizes that offer ESO. Other studies may compare the impact of the financial results of the two ESO valuation methods sanctioned by the FASB to the impact that results when employing the Simple model. Finally, studies may focus on samples of companies with certain financial characteristics or those operating in certain industry sectors.

\section{REFERENCES}

1. Aboody, D., Barth, M. E., and Kasznik, R., (April 2004), SFAS 123 Stock-Based Compensation Expense and Equity Market Values, The Accounting Review, 251-275.

2. Aboody, D., Barth, M. E., and Kasznik, R., (May 2004), Firms' Voluntary recognition of Stock-Based Compensation Expense, Journal of Accounting Research, 123-150.

3. Accounting Principles Board, (October 1972), APBO No. 25: Accounting for Stock Issued to Employees. American Institute of Certified Public Accountants (AICPA), New York.

4. Apostolou, N. and Crumbley, D., (May 2001), Accounting for Stock Options: The Controversy Continues, The CPA Journal, 34-39.

5. Apostolou, N. and Crumbley, D., (August 2005), Accounting for Stock Options: Update on the Continuing Conflict, The CPA Journal, 30-33.

6. Balsam, S., (December 1994), Extending the Method of Accounting for Stock Appreciation Rights to Employee Stock Options, Accounting Horizons, 52-60.

7. Barenbaum L., Schubert, W., and O'Rourke, B., (December 2004), Valuing Employee Stock Options Using a Lattice Model, The CPA Journal, 16-20.

8. Baril, C. P., Betancourt, L., and Briggs, J. W., (December 2005), How to Excel at Options Valuation, Journal of Accountancy, 57-63.

9. Bartow, E. and Mohanram, P., (October 2004), Private Information, Earnings Manipulations, and Executive Stock-Option Exercises, The Accounting Review, 889-921.

10. Baviera, G. J and Walther, L. M., (May 2004), Stock Option Accounting: Defying the Usual Answers, The CPA Journal, 36-38.

11. Beams, J. D., Amoruso, A. J., and Richardson, F. M., (December 2005), Discretionary Reporting of Stock Options by IPO Firms, Accounting Horizons, 223-236.

12. Best, R., Rue, J., and Volkan, A., (Winter 2002), Impact of Stock Options on Quarterly EPS: A Proposal for Change, International Business and Economics Research Journal, 73-82.

13. Black, F. and Scholes, M., (May 1973), The Valuation of Option Contracts and a Test of Market Efficiency, The Journal of Finance, 399-417.

14. Botosan, C. and Plumlee, M., (December 2001), Stock Option Expense: The Sword of Damocles Revealed, Accounting Horizons, 311-327.

15. Briloff, A., (December 2003), Accounting for Stock Options, The CPA Journal, 12-15.

16. Dechow, P., Hutton, A., and Sloan, R., (Supplement 1996), Economic Consequences of Accounting for Stock-Based Compensation, Journal of Accounting Research, 1-20. 
17. Delves, D., (December 2002), Trend or Foe? Analyzing What's Behind and Beyond the Current Stock Option Expensing Movement, Strategic Finance, 36-41.

18. Deshmukh, S., Howe, K. M., and Luft, C., (July 2004), Stock Option Expensing and Corporate Governance: When Will the Debate End?, Strategic Finance, 41-44.

19. Doyle, W., (February 1997), New Accounting Principles for Stock-Based Compensation, Management Accounting, 38-42.

20. Dyson, R. A., (August 2004), Accounting for Stock-Based Compensation: A Simple Proposal, The CPA Journal, 6-10.

21. Eaton, T. V. and Prucyk, B. R., (April 2005), No Longer an Option, Journal of Accountancy, 63-68.

22. Financial Accounting Standards Board, (December 1978), FASB Interpretation No. 28: Accounting for Stock Appreciation Rights and Other Variable Stock Option or Award Plans, FASB, Norwalk, CT.

23. Financial Accounting Standards Board, (1985), Statement of Financial Accounting Concepts No.6: Elements of Financial Statements, FASB, Norwalk, CT.

24. Financial Accounting Standards Board, (July 1986), Discussion Memorandum: Accounting for Stock Options, FASB, Norwalk, CT.

25. Financial Accounting Standards Board, (1993), Exposure Draft: Accounting for Stock-Based Compensation, FASB, Norwalk, CT.

26. Financial Accounting Standards Board, (1995), Statement of Financial Accounting Standards No 123: Accounting for Stock-Based Compensation, FASB, Norwalk, CT.

27. Financial Accounting Standards Board, (October 2000a), Exposure Draft: Proposed Amendment to FASB Concept Statement \#6 to Revise the Definition of Liabilities, FASB, Norwalk, CT.

28. Financial Accounting Standards Board, (October 2000b), Exposure Draft: Accounting for Financial Instruments with Characteristics of Liabilities, Equities, or Both, FASB, Norwalk, CT.

29. Financial Accounting Standards Board, (November 2002a), Invitation to Comment: Accounting for StockBased Compensation, FASB, Norwalk, CT.

30. Financial Accounting Standards Board, (December 2002b), Statement of Financial Accounting Standards No. 148: Accounting for Stock-Based Compensation-Transition and Disclosure, FASB, Norwalk, CT.

31. Financial Accounting Standards Board, (May 2003), Statement of Financial Accounting Standards No. 150: Accounting for Certain Financial Instruments with Characteristics of both Liabilities and Equity, FASB, Norwalk, CT.

32. Financial Accounting Standards Board, (December 2004), Statement of Financial Accounting Standards No. 123 (R): Share-Based Payment, FASB, Norwalk, CT.

33. Financial Accounting Standards Committee of the American Accounting Association, (June 1994), Response to: FASB Exposure Draft - Accounting for Stock-Based Compensation, Accounting Horizons, 114-116.

34. Financial Accounting Standards Committee of the American Accounting Association, (March 2004), Evaluation of the IASB's Proposed Accounting and Disclosure Requirements for Share-Based Payment, Accounting Horizons, 65-76.

35. Financial Accounting Standards Committee of the American Accounting Association, (June 2005), Response to the FASB's Exposure Draft on Share-Based Payment: An Amendment of FASB Statements No. 123 and No. 95, Accounting Horizons, 101-114.

36. Hemmer, T., Matsunaga, S., and Shevlin, T., (December 1994), Estimating the Fair Value Of Employee Stock Options with Expected Early Exercise, Accounting Horizons, 23-42.

37. Hill, N. and Stevens, K., (1997), Instructional Case: Choices and Dilemmas in Accounting For Stock-Based Compensation, Journal of Accounting Education, Vol. 15 (7), 389-410.

38. Hull, J. and White, A., (2004, 1:1), Accounting for Employee Stock Options: A Practical Approach to Handling the Valuation Issues, Journal of Derivatives Accounting, 3-9.

39. International Accounting Standards Board (November 2002), Exposure Draft 2: Share-Based Payment, IASB, London.

40. International Accounting Standards Board (April 2004), IFRS \#2: Share-Based Payment, IASB, London.

41. Kirschenheiter, M., Mathur, R., and Thomas, J. K., (June 2004), Accounting for Employee Stock Options, Accounting Horizons, 135-156.

42. Lobo, G. and Rue, J., (Summer 2000), Accounting for Stock Options: Comparison of Alternative Approaches, The Journal of Applied Business Research, 27-38. 
43. Mellman, M. and Lillien, S., (March 1996), Stock-Based Compensation Effect on Net Income, The CPA Journal, 50-53.

44. Moehrle, S. R. and Reynolds-Moehrle, J. A., (June 2004), Transitioning to the Fair Value Method, The CPA Journal, 20-22.

46. Moyer, S. and Weihrich, S., (August 2000), Espresso, Inc.: Analyzing the Impact of Employee Stock Options, Issues in Accounting Education, 513-534.

47. Pacter, P., (March 1994), FASB's Stock Option Accounting Proposal: Correcting a Serious Flaw, The CPA Journal, 60-61.

48. Perspectives, (January-February 1994), Letters to the Editor, Harvard Business Review, 27-36.

49. Robinson, D. and Burton, D., (June 2004), Discretion in Financial Reporting: Voluntary Adoption of Employee Stock Options, Accounting Horizons, 97-108.

50. Rue, J., Volkan, A., Best, R., and Lobo, G., (November 2003), Stock Options Revisited, The CPA Journal, $34-40$.

51. Siegel, M. A., (March 2006), Accounting Shenanigans on the Cash Flow Statement, The CPA Journal. 3843.

52. Tucker, J. and Shimko, B., (January 1995), The Economic Impact of the Proposed Rule Change for Employee stock Options: The Issues and Controversy, American Business Review, 8-10.

53. Wallace, W., (April 1984), The Effects of Delays by Accounting Policy-Setters in Reconciling the Accounting Treatment of Stock Options and Stock Appreciation Rights, The Accounting Review, 325-341.

\section{NOTES}

